\title{
A közgazdász hivatásáról Fiatal közgazdászok a közgazdász szakmáról
}

A Köz-Gazdaság szerkesztősége mindig kiemelt figyelmet fordított az új közgazdászgeneráció szakmai irányultságának bemutatására. Két alkalommal is ennek jegyében kértük fel a Magyar Közgazdasági Társaság Ifjúsági Bizottságával közösen az egyes egyetemi szervezeteket, hogy fejtsék ki álláspontjukat a közgazdász szakma jelenlegi állapotáról. Első körben a kérdésekre Bencsik Ildikó, az Ifjúsági Bizottság elnöke, Fekete Bálint, az MKT BME vezetője, Kunkli Gréta, a Debreceni Egyetemen működő MKT szervezet vezetője, Lits Levente, az MKT Corvinus vezetőségi tagja, Sántha Izabella, szintén az MKT BME vezetőségi tagja és Szabó Dorottya, az MKT Corvinus elnöke válaszolt. Ezt követően egy online beszélgetést szerveztünk, melyen a Debreceni Egyetemről Kunkli Gréta, az MKT Corvinus részéről Halász Győző Mihály, Lits Levente, Kunsági Zsóka vett részt, illetve vendégünk volt Bencsik Ildikó, az Ifjúsági Bizottság elnöke. Ez a beszélgetés a cikk második részében található.

\section{Mit tekintenek a közgazdász, hivatásának, mi a közgazdász feladata a társadalomban?}

Bencsik Ildikó: A XXI. század közgazdászainak feladata véleményem szerint a múlt kiértékelése közgazdasági szemmel, a jelen gazdasági eseményeinek vizsgálata és magyarázata (ok-okozati összefüggések, mechanizmusok keresése), valamint a jövőre vonatkozó előrejelzések meghozása. Ez utóbbi feladat szinte lehetetlen, azonban előfordulhatnak olyan helyzetek, hogy a jelenlegi döntések meghozatalának függvénye valamilyen lehetséges jövőbeli szcenárió feltételezése, így a közgazdászoknak a különböző közgazdasági modellek segítségével meg kell becsülniük a legvalószínűbb jövőképet.

Fekete Bálint: Véleményem szerint a közgazdász az a személy, aki a társadalomtudományok átfogó ismerete alapján politikai javaslatokat tud tenni. Hisz a fö döntéshozó szerv - a kollektív társadalmi kérdésekben - az állam, amelynek döntéseit támogatni kell. A politika társadalomirányító szervként értelmezése segít abban, hogy a közgazdászokat egyfajta döntéstámogató rendszerként kezeljük. Emellett természetesen úgy gondolom, a vállalati szektor vezetői is közgazdászok, attól függetlenül, hogy tanultáke a szakmát, vagy munkájuk során elsajátították. Úgy gondolom, aki vezető beosztásban dolgozik, annak közgazdásznak IS kell lennie, bármiről is legyen szó.

Kunkli Gréta: Véleményem szerint ez egy nagyon összetett hivatás, ez az első dolog, ami mindig az eszembe jut róla. Ahogyan a közgazdaságtan, úgy a közgazdászok hivatása is szerteágazó, mindenkinek meg kell találnia a szerepét ebben a bonyolult gépezetben. Rettentően komplex és számos készség elsajátítását igényli. Egy közgazdász feladata a társadalomban nemcsak az aktuális gazdasági, pénzügyi állapotokat elemezni és értékelni, hanem legfőképp előre látni, és felkészíteni a társadalmat az egyes gazdasági helyzetek lehetséges következményeire, valamint megoldások találása a kialakult problémákra. Egy közgazdász feladata az, hogy a gazdaság a lehető legolajazottabban müködjön. Ehhez köteles akár elméletben, akár gyakorlatban hozzájárulni. Szerintem különbséget kell tennünk a közgazdászok és a vállalkozók, üzletemberek között, mivel a kettő között eltérő háttértudás van, illetve a szükséges kompetenciák is különböznek.

Lits Levente: Úgy gondolom, a közgazdaságtan nem értéksemleges szakma, és a közgazdász társadalomnak éppen ezért mindent meg kell tennie, hogy az e területen gondolkozók, teoretikusok és alkotók a lehető legsokfélébben tudják leírni a társadalmakat és azok müködéseit, eljuttatva elgondolásaikat 
a nagyérdemühöz, hogy az párbeszédet folytatva, megértve, integrálva a mindenkori társadalmak és az emberiség hasznára váljon. Természetesen, mint minden hasonló értelmiségi csoportnak, nekünk is hatalmas felelősségünk van a politika és a társadalmak helyes szervezésében, müködtetésében.

Sántha Izabella: Egyfajta válságmenedzser, akinek feladata, hogy két társadalmi-gazdasági korszak változása közötti átmeneti időszakot menedzselje. Egy olyan személy, aki érti és ismeri a társadalmi folyamatokat, és ezeket le tudja fordítani a gazdaság nyelvére.

Szabó Dorottya: A közgazdász feladata a mindenkori közjó előmozdítása. A szabadságnak, jólétnek és a tágan értelmezett boldogságnak mindig is voltak anyagi feltételei, és mindig is lesznek. Úgy gondolom, hogy a közgazdászoknak azért kell dolgozniuk, hogy ezen feltételek a társadalom egésze számára egyenlő eséllyel legyenek megteremthetők. Ennek alapja egy olyan gazdasági rendszer tervezése és fenntartása, melyben az egyéni érdekek egybeesnek a közjóval.

\section{Önök szerint hogyan lehet összefoglalni a közgazdászok szakmai etikáját? Még a 2008-as válság kapcsán megfogalmazódott, hogy a közgazdászoknak is kellene szakmai esküt tenniük a hippokratészi eskü mintájára. Egyetértenek ezzel? Ha igen, akkor Önök szerint mit kellene tartalmaznia ennek az eskünek?}

Bencsik Ildikó: A közgazdászok szakmai etikáját úgy tudnám megfogalmazni, hogy az elemzéseink során törekednünk kell arra, hogy minden rendelkezésünkre álló információt, adatot megvizsgáljunk és amennyiben releváns az információ, adat és hiteles forrásból származik, beépítsük a közgazdasági modellünkbe. Az eredmények, konklúziók megfogalmazásakor, a közgazdasági döntések meghozatalakor pedig tartózkodnunk kell a politikai hatalmak nyomásgyakorlásától, demagógiájától. A szakmai esküt kevésbé tartom jó "motivációnak", mint például a közgazdasági témájú díjakat, kitüntetéseket vagy egyszerűen egy közgazdász jó megítélését. Véleményem szerint nem az eskü befolyásolja egy közgazdász tevékenységét, munkavégzését, hanem a megfelelö ösztönzők és körülmények.

Fekete Bálint: A közgazdaságtan magas szintü tudása rendkívül értékes kincs, nem is nehéz vele visszaélni, de nem gondolom szükségesnek a hippokratészi esküt. Inkább szűkíteném azon képzések listáját, melyek közgazdász végzettséget adnak. Gondolok itt arra, hogy aki marketingesként szeretne foglalkozni, őt inkább nevezzük üzemgazdásznak, és ne közgazdásznak, mint ahogy akár az angol, akár a német nyelvterületen elkülönítik egymástól a "business" és az "economist" képzéseket. Ez nem értékítélet, csak arról van szó, hogy a képzés iránya más jellegü. Hasonlóképpen, aki egy vállalatot vezet, ne hívjuk közgazdásznak.

Kunkli Gréta: Mivel olyan szakmáról beszélünk, ahol a versengés, a versengő magatartás alapvető, a közgazdászok szakmai etikáját nehéz lenne meghatározni. Az viszont biztos, szerepelnie kell az olyan intézkedések, tevékenységek kerülésének, amelyek hosszú távon képesek mindenkinek kollektíven rosszat okozni. A Magyar Közgazdasági Bizottság Debreceni Ifjúsági Bizottságának vezetősége egyetért abban, hogy egy ilyen „közgazdász-eskü” nem feltétlen szükséges, vagy nem pontosan erre lenne szükség, hiszen látunk arra éppen elég példát, hogy ahol esküt kell tenni, ott sem feltétlenül tartják be a benne foglaltakat. Ennek ellenére vannak olyan alapelvek, amelyeket nem szabad szem elől téveszteni. Ennél a hivatásnál elvárandó, hogy egy közgazdász felelős állampolgárként viselkedjen. Valamint, mint szakember, valós és hiteles információkkal szolgáljon, illetve elsődlegesen ne önös, hanem társadalmi érdekek vezéreljék döntéseiben.

Lits Levente: Nem hinném, hogy ez megoldás lenne. A Biblia megfelelő szakaszainak ismerete nem kellene, hogy problémát jelentsen semelyik, az európai kultúrkörből származó közgazdásznak amellett, 
hogy nem pusztán az egyéni hibákban, hanem mélyebb gyökereikben, rendszerszinten fedezendők fel értékrendi ellentétek, egyet nem értések.

Sántha Izabella: Azt gondolom, hogy mint minden más szakmában, a legfontosabb, hogy mindig a legjobb tudása alapján, szakmailag megalapozottan járjon el, és folyamatosan kérdőjelezze meg az álláspontja helyességét, hiszen ezt tudja az élethosszig tartó tanulásra ösztönözni. Az eskü ötletével nem értek egyet, hiszen napjainkban számos egyetemi szak közgazdász végzettséget ad (például kereskedelem és marketing, turizmus és vendéglátás, gazdálkodási és menedzsment stb.), ugyanakkor azok elvégzői gyakran teljesen más területeken kívánnak elhelyezkedni, így már a tanulmányaik során sem a közgazdaságtanra helyezik a hangsúlyt. Mindez az oktatók számára is megnehezíti, hogy a közgazdasági elveket úgy átadják a hallgatók számára, hogy ők készségszinten meg is tanulják azokat.

Szabó Dorottya: Határozottan támogatnék egy hippokratészi típusú esküt a közgazdász szakmában is. A közgazdászok rengeteg olyan pozíciót töltenek be, amelyben emberi sorsokról, egzisztenciáról döntenek. Például egy munkavállaló elbocsátása, egy adókulcs emeléséről való döntés, vagy az egészségügyi finanszírozás visszafogása mind olyan döntések, melyek egész családok életére nagy hatást gyakorolhatnak. A megfelelő foglalkoztatás-, gazdaságpolitikai eszközök precíz és pontos alkalmazása véleményem szerint épp akkora felelősség, mint amikor az orvosnak megfelelően kell bánnia a szikével. Egy ilyen jellegü eskü természetesen nehezen kérhető számon sokszor még az orvosok esetében is, de fontosnak tartom magát az elvet. Szembesüljön a közgazdász eskü formájában azzal, hogy a szakmájával semmilyen körülmények között nem élhet vissza, hogy a tudásával másokat kell szolgálnia, és hogy sohasem a saját gazdagodása a szakmája értelme.

\section{Mit gondolnak, az Önök szakmai pályafutásában mi lesz a legnagyobb kihívás, minek kell megfelelni a következö évtizedekben? Hogy látják, a technológiai fordulat (4. ipari forradalom, új technológiai korszak stb.) megváltoztatja-e a közgazdasági gondolkodást vagy érintetlenül fogja hagyni?}

Bencsik Ildikó: A legnagyobb kihívás számunkra az lesz, hogy az elemzéseinkhez, modelljeinkhez szükséges adatforrást megfelelően megválasszuk. A Big Data korában egyrészt könnyű dolgunk van, hiszen rengeteg mennyiségü adat áll rendelkezésünkre, ezáltal szinte mindenről van adatunk, mindent tudunk mérni. Ugyanakkor amiatt, hogy az adatforrások száma gyakorlatilag exponenciális növekedésnek indult, nehezebb megbizonyosodnunk az adatok hitelességéről is. Tehát maga a közgazdasági modell megalkotása egy-egy problémára játszi könnyedséggel megoldható, azonban a modell jóságának biztosítása és a megfelelő konklúziók levonása már a leggyakorlottabb közgazdászoknak is fejtörést okozhat. A 4. ipari forradalom és a megjelenő eddig ismeretlen jelenségek és eszmék, mint ahogy minden nagyobb korszakváltás, a közgazdasági gondolkodást is formálni fogja, nem csak a modellalkotást. Az a várakozásom, hogy a viselkedési közgazdaságtan még erőteljesebb szerepet fog vállalni a közgazdasági szemléletek között.

Fekete Bálint: A 21. század egyik legnagyobb kihívása a humántőke értékének alacsony színtü kihasználtsága. A humántőke-elmélet beárazhatóvá tette az embereket. Mindenkinek van egy kiszámítható jelenértéke. Tegyük fel, hogy diplomám megszerzése után elmegyek dolgozni egy céghez, mellette tanulok tovább. Telik az idő, a nettó jelenértékem nő a fizetésemmel és a tanult idővel együtt. Az informatika is fejlődik ez idő alatt, így létre tudnak hozni olyan algoritmusokat, mely ellátja helyettem a feladatokat. Rám már nincs szükség a cégnél, elbocsátanak. Munkát kell keresnem, a kihasználatlan idő csökkenti a jelenértékemet, tehát az a sok érték, amit eddig felhalmoztam, csökken. Valószínűleg előbb-utóbb nagyon 
sok munkahelyet robotokkal helyettesítenek majd, így a humántőke kihasználtsága csökkenni fog. Nem gondolom erre megfelelő válasznak azt, hogy használjuk ki máshogy, hisz erre kevesen lesznek képesek, így a globális különbségek tovább fognak nőni. A 80/20 Pareto-szabály a 22. századra 98/2 lesz. (Ez csak a véleményem, a szám csak szemléltetés, tudományos felmérés nem adja ennek alapját.)

Kunkli Gréta: A folyamatos változás lesz a legnagyobb kihívás, és globális problémák megoldása. Ez fogja formálni a közgazdászok gondolkodását. A digitális technológia fejlődése magától értetődően rengeteg más iparágra is hatással van, nincs ez azonban másképp a különböző társadalmi trendek esetében sem. A technológiai fordulat már most elérte a közgazdaságtan tudományát is. Új világ tárult elénk, és ez a jövőnket is befolyásolni fogja. Ehhez alkalmazkodni kell, és ki kell használni az ebböl származó előnyöket. A közgazdászoknak ennek ellenére nem kell informatikusoknak lenni, de nem ragadhatnak meg a múltban. A sok információ közepette nehéz elhinni azt, hogy lehet újítani, de mindig vannak és lesznek olyanok, akik erre rácáfolnak. A közgazdaságtannak együtt kell haladnia a korral, sőt meg is kell előznie azt, ami a becslések, várakozások, előrejelzések területét illeti.

Lits Levente: A technológiai fordulat a közgazdász szakma beszükülését fogja magával hozni, így sokaknak e téren nem biztosított hosszú távon a munkahelye, ellenben rávilágíthat annak mélyebb aspektusaira, így elmozdulás történhet a társadalomtudományok felé, és a lakosság is kevésbé fogja természettudományosnak látni. A főbb kihívásokra tekintettel szinte teljes egyetértés van, a környezeti és társadalmi válságok sorát kell felszámolnia ennek a generációnak, megteremtve a harmóniát ember és ember, valamint ember és természet között.

Sántha Izabella: Leginkább a negatív demográfiai folyamatok kezelése lesz a legnagyobb kihívás, az egészségügyi és a nyugdíjrendszer megreformálása.

Szabó Dorottya: A következő évtizedek legnagyobb feladata azt gondolom, még a 20. század végéről maradt ránk. Egy olyan gazdaságelméleti keretet kell kidolgoznunk, ami mentes a szélsőséges ideológiáktól, egy olyan párbeszédet kell kialakítanunk, ami lehetővé teszi a múlt tanulságaiból való okulást, és a múlt bölcsességeinek 21. századi alkalmazását. Egy egységes elméleti keretben tudnak olyan gyakorlati megoldások születni, ami globális szinten mozdítja elő az emberek jólétét. A nyugati és a keleti kultúra gyökereiben is fellelhető a munka alóli felszabadulás vágya, az emberiség egyik - talán megkérdőjelezhetetlenül közös célja a szabad élet. Az új technológiai korszak új lehetőségeket teremt arra, hogy közelebb lépjünk ehhez a közös célhoz.

\section{Mit gondolnak az Európai Unió jövőjéröl? Önök szerint erősödni fog az integráció vagy a nemzetállamok szerepe növekszik majd? Hogy látják a magyar felzárkózási folyamatot, mely pontokon lesz elkerülhetetlen a változás, és milyen tekintetben sikerült a felzárkózás?}

Bencsik Ildikó: Véleményem szerint folytatódni fog az Európai Unió széttagozódása, kisebb csoportok fognak kialakulni, akik egymással különböző egyezményeket kötve "mini uniókat" hoznak létre a nagy unión belül. Azt a szélsőséges szcenáriót egyelőre nem tartom valószínűnek, hogy teljesen felbomlik az Európai Unió. A magyar felzárkózási folyamattal kapcsolatban sajnos inkább pesszimista gondolataim vannak, az ország és a magyar gazdaság vezetése nem tudatosan, nyílegyenesen egy (vagy néhány fó) cél felé tart. Sokkal inkább hasonlít ez a "fejlődési" folyamat egy bumeráng útjára, amely mindig majdnem eléri a kitüzött célt, de valahogyan mégis visszajut a kiindulóponthoz, arra a szintre, ahol elkezdődött a folyamat. Ez persze nem azt jelenti, hogy egyáltalán nem volt fejlődés, több területen sikerült pozíciót javítanunk a többi, hasonló gazdasági felépítéssel és potenciállal rendelkező EU-s országhoz képest, 
gondolok itt például az ICT ágazatokra, amelyben komoly humán kompetenciával rendelkezünk, ráadásul a vezetékes és mobil szélessávú lefedettségünk is átlagon felüli, továbbá a beruházások növekedésével a foglalkoztatottsági rátán is sikerült javítani (a COVID-19 előtti időszakig).

Fekete Bálint: Az EU jövőjét illetően azt gondolom, a jelenlegi berendezkedés csak a tagállamok lakosságának felébredéséig tud így maradni. Magyarország felzárkózása remekül megy, és nagyon örülök neki, hogy nem partner a globális liberalizációban. Sokszor hallom, hogy a „liberalizmus a jövő”. Ha engem kérdeznek, semmiképp. Az EU jelenlegi legnagyobb romboló ereje az időpazarlás. Ilyen-olyan cikkelyek megalapozatlan dobálása tagállamokra, akik nem hódolnak be. Ha nem jön valaki, aki rendet csinál a szervezett népbutításban, az Európai Unió meg fog bukni, csak a népbutítás eljutott oda, hogy az emberek nem értik, mi történik körülöttük. Válaszomban nem az Európai Uniót, mint intézményt kritizálom. Igenis egyetértek vele, és nagyon hasznosnak gondolom, pláne Magyarországra nézve, hisz többet kapunk vissza jóval, mint amennyit beteszünk. Magyarországnak hatalmas segítség ez. Az Európai Unió jelenlegi berendezkedését kritizálom, aminek nem csak a tagállamok közötti redisztribúció a feladata.

Kunkli Gréta: A vezetőség egy része egyetért abban, hogy ezt nehéz lenne megjósolni, viszont az biztos, hogy a koronavírus okozta járvány következtében mind a két irányra láthattunk példát. Egyrészről rendkívül fontos szerepet játszott az integráció, hogy minden tagállam egyaránt komolyan vegye, és közösen próbálja meg leküzdeni a járványt, viszont a nemzetállamok szerepe erősödött abból a szempontból, hogy mindegyik országnak sok problémát magának kellett megoldania, sok esetben ellátnia magát. Véleményem szerint a járvány következében az ellátási láncok is rövidülnek, és nagyobb hangsúly kerül a hazai termelésre, illetve több területen nagy az egyet nem értés. A gazdasági szempontokat figyelembe véve Magyarországnak jelentős haszna van az unióhoz való tartozásból, a befolyó források elősegítik a magyar felzárkózási folyamatot. A figyelem azonban nem koncentrálódhat csak az Európai Unióra, és az is igaz, hogy az integráció kérdésében sem egyedül a magyar érdekek dominálnak. Egyikőnk szerint azonban az integráció erősödni fog, a jelenlegi fokozott globalizáció pedig a fejlődő országok kultúrájára is hatással lesz. A nemzetállamiság a fejlődő országokban csökkeni fog, itt a fejlett országokkal való szimpátia fog növekedni. A fiatalabb generációknak itt rendkívül nagy szerepe van: digitális bennszülöttként már képesek személyiségüket egy másik ország normája szerint is kialakítani.

Lits Levente: A globalizációs folyamatok figyelembevételével ahhoz, hogy itt Európában megőrizhessük politikai, illetve gazdasági befolyásunkat, nem is beszélve a szociális és környezeti szempontokról, mindenképpen egy jobban szervezett európai társadalmat kell felépíteni, annak egészségügyi, oktatásügyi, hadügyi, demokratikus képviseleti, illetve kereskedelmi aspektusait tekintve. Az integráció minősége és erőssége terén természetesen sok álláspont létezik és értékrendi viták is várhatók, de a nemzetállami müködéshez, amennyiben az egyetemes értékrendi kérdések tagállami szintű rendezését értjük azalatt, sosem fog visszatérni egyik közösség sem, ugyanis a kereskedelem is, mint a gazdaság része, értékrenden alapszik, így az izolációt jelentene.

Sántha Izabella: Bizonyos területeken egyre erősebb lesz az integráció, a tagállamok szakpolitikáinak összehangolása. Ilyen például a környezetpolitika, hiszen a globalitás miatt a környezeti károk okozásában az érintettek (károsultak) gyakran nem olyan arányban felelősek, mint ahogy részesülnek azokból.

Szabó Dorottya: Azt gondolom, hogy a hosszú távú politikai érdekeket az Európai Unió tagországainak erősebb gazdasági-társadalmi integrációja szolgálná. A magyar felzárkózási folyamat az én szememben gyengének tünik fel. Amíg a feudalizmus maradványaival, a posztszocializmus és -fasizmus tüneteivel küzdünk, addig ez az ország saját maga alatt vágja a fát. 


\section{Szakmai karrierjük során gondolkodnak-e külföldi munkavállalásban, és ha igen, mennyire hosszú távon? Hogy látják ugyanezt pályatársaik esetében? Mi a meglátásuk, a külföldi tapasztalat miben tudja Önöket segíteni? Mely régióban, országban szeretnének tapasztalatot szerezni elsösorban (más EU-s tagállam, Nagy-Britannia, USA, Kína, más ország)?}

Bencsik Ildikó: Rövid távon nem gondolkodom külföldi munkavállalásban, azonban 5-10 éven belül elképzelhetőnek tartom, hogy egy néhány hónapos, maximum féléves külföldi tapasztalatszerzésre szegődjek, s azt is valahol - ha nem is az Európai Unión, de - Európán belül. Pályatársaim tekintetében azt vettem észre, hogy aki a mesterszakos diplomáját külföldön szerezte meg, vagy több mint egy évet kint tanult, az szinte biztosan külföldön maradt dolgozni és élni is. Személy szerint azért vágnék bele külföldi tapasztalatszerzésbe, hogy közvetlenül megismerkedhessek a külföldiek munkamoráljával, a munkához, feladathoz és az élethez való hozzáállásukkal, s ha tudok, tanuljak ezekből a felismerésekből. Nem utolsósorban pedig azért utaznék külföldre munkát vállalni, hogy magabiztosabb angoltudással és értékes külföldi kapcsolatokkal, élményekkel térhessek haza.

Fekete Bálint: Nem tervezek külföldön munkát vállalni, magyar vagyok, Magyarországon fogok dolgozni.

Kunkli Gréta: A vezetőségünk minden tagja gondolkozott már ilyesmin. Elsősorban a szakmai éleslátás miatt, amivel kiemelkedhetek a magyar munkaerőpiacon. Rendkívül hasznos lehet az ismeretszerzés, nyelvtanulás és a kapcsolatok kiépítése szempontjából. A koronavírus miatt ezek a tervek egy ideig még elképzelések maradnak, de bízom benne, hogy idővel valóra válhatnak. Mindegyikőnk rövid távon (1-2 év) időtartamban gondolkozik. Ha pedig rendkívül előnyösek a kinti munkalehetőségek, csökken a külföldi munkavállalók diszkriminációja, és lehetőség is lesz, akkor a kiköltözést is meg merné kockáztatni egyikünk. A másik lehetőség az Erasmus külföldi tanulmányi pályázat az egyetemi tanulmányaim kezdetén egy másik EU-s tagállamban, mivel nagyon jónak tartom kapcsolatépítés, nyelvtanulás és szakmai ismeretszerzés területén is. Bár nőként hosszú távon belép egy fontos szempont: nem hagynánk itt a családunk. Célterületeink: Svájc, Nagy-Britannia, USA, Németország, Ausztria, Spanyolország, hasonló EU-s tagállamok Pályatársaink esetében ez változó, de a legtöbbször azt tapasztaltam, hogy szívesen kipróbálnák a külföldi munkavállalást, de nem túl hosszú távon, esetleg egy-két év erejéig egy Európán belüli államban.

Sántha Izabella: Nem gondolkodom külföldi karrierben. Alapvetöen sosem volt tervem külföldön karriert építeni, és ebben a Münchenben töltött tanulmányi félévem még jobban megerősített. A kint töltött 5 hónap rávilágított arra, hogy egy nyugat-európai, fejlettebb nagyvárosban is ugyanúgy megtalálhatóak azok a problémák, amelyekről azt gondolnánk, hogy csak ránk igazak. Arra is rájöttem, hogy a magasabb fizetés nem feltétlen járna magasabb életszínvonallal, hiszen a végcélom úgyis az lenne, hogy hazajövök, ezért a lehető legnagyobb összeget félretenném megtakarítani. Emellett vannak olyan tényezők (például az anyanyelvünk használata, család, barátok elérhető közelsége, a tudat, hogy a munkámmal a szülőországomnak visszaadhatok valamit), amelyeket nem lehet jobb karrierlehetőségekkel pótolni. A müncheni szemeszter során számos hasznos tapasztalatot gyüjtöttem, például arról, hogy milyen egy multikulturális háttérrel rendelkező csapatban a tagokkal együtt dolgozni. Emellett megismerhettem, hogy mik lehetnek azok a plusz munkáltatói (egyetemi) szolgáltatások, amelyek segítenek a munkavállalók (hallgatók) szakmai fejlődésében (például angol nyelvű egyetemi beadandó, szakdolgozat, motivációs levél stb. ellenőrzése és korrekciója anyanyelvi diákok által). Úgy gondolom, hogy a külföldi munkavállalásnak is hasonló előnyei lehetnek. A mesterképzésem során is szeretnék egy félévet külföldön tanulni, mindenképp EU-s országban gondolkodom. Pályatársaimon is azt látom, hogy külföldi munkavállalás terén 
maximum egy éves időszakban gondolkoznak (a gimnázium és egyetem között gap yeart tartanak és kimennek au-pair-nek), viszont külföldi tanulmányokban annál inkább. Igen népszerű az Erasmus ösztöndíjjal egy vagy két félévet külföldön tölteni, vagy a teljes mesterképzést külföldön végezni. Itt is az EU-s országok a legnépszerübb célpontok: Portugália, Spanyolország, Olaszország, Németország.

Lits Levente és Szabó Dorottya: A külföldi tapasztalatszerzést nem önmagában tartom fontosnak, és nem gondolom, hogy a 17., 18. században véletlenül terjedt volna el az arisztokratikus-intellektuális utazások „divatja”. Ahhoz, hogy hitelesen szólaljunk meg egy globalizált világ gazdasági-társadalmi rendszereiről, azt gondolom, szükségünk van olyan tapasztalatokra, melyeket teljesen más kultúrákban élve szerzünk meg. Ha az életem egy pontján minden feltétel adott lenne ahhoz, hogy akár többéves külföldi kiküldetésbe „számüzzem” magam, ezer örömmel indulnék el, és biztos vagyok benne, hogy az életemnek egy következő pontján bölcsebben térnék haza Magyarországra, hogy a magyar emberek jólétéért dolgozzak.

\section{„a mi felelősségünk is, hogy a gazdálkodó erkölcsösen viselkedjen”}

A világjárvány után érezhetö, hogy egy új középtávú gazdaságpolitikai korszak kezdödik el. Mit gondolnak erről a korszakhatárról? Miben fog átalakulni a tág értelemben vett gazdaságpolitika, milyen új tendenciák jelennek meg, és ezekre hogyan fog reagálni a közgazdaság-tudomány, illetve az egyes gazdaságtudományi diszciplínák?

Bencsik Ildikó: Bízom benne, hogy a következő években több pénzt fognak ez egészségügybe fektetni, hogy a járványokat felkészültebben tudjuk kezelni.

Kunkli Gréta: Szakmák hangsúlyossága meg fog változni véleményem szerint. Az egészségügy sokkal fontosabb tünik most hirtelen például a turizmussal szemben. Megítélésük változik, felborulhat fontossági sorrend, munkarend is meg fog változni szerintem. Nem fognak visszaállni az irodai munkára az egyes szektorokban. Teljes home office-ra átállás is történhet, ezzel megelőzve, hogy egy újabb válsághelyzet esetén hirtelen sok embernek kelljen otthoni munkára átállni.

Lits Levente: Foglalkoztatási modellben látok változást, meg fog szünni a periféria-félperiféria viszony. Elindul egy átalakulás a tudásalapú társadalom irányába. Az online térben megjelenő véleményeket a tudás fogja ellensúlyozni. A tudomány és a filozófia is választ fog erre adni. A technika kritikája is meg fog jelenni az elkövetkezendő időszakban. Ezekre a változásokra a gazdaság és a társdalom is reagálni fog.

Kunsági Zsóka: Úgy gondolom az alternatív irányzatok erősödnek a közgazdaságtanban. Ennek kapcsán én úgy érzékelem, hogy megváltoztak a fogyasztási szokásaink.

A következö tíz-tizenöt évben milyen fö veszélyforrásokat látnak a gazdaságban (klímaváltozás, újabb járvány stb.)? Ezekre hogyan lehet majd felkészülni gazdaságilag? Az Önök korosztálya mennyire tart egy újabb válságtól, és hogyan készül ezekre? Látnak-e mentalitásbeli különbséget ebben a tekintetben az idösebb közgazdászokhoz képest? Mit gondolnak, milyen technológiai tendenciákra kell odafigyelni a következö tíz évben, amihez majd gazdaságpolitikai és üzleti modelleket érdemes kialakítani?

Bencsik Ildikó: Az egyik veszélyforrásnak érzem a magasabb munkanélküliséget. Sokan nehezen tudtak alkalmazkodni a hirtelen jött új helyzethez. Remélem, olyan intézkedések fognak történni, amik elősegítik az átállást az új kihívásokhoz és segítik a megváltozott világban az elhelyezkedést. Szerintem például a turizmus jelentősége csökkeni fog a jövőben. 
Kunkli Gréta: Fel kell készülnünk újabb válságokra, gondoljunk itt akár csak a klímaváltozásra. Ki kell alakítanunk krízisprotokollokat és frissíteni a meglévőket. A cégeknél a legtöbb válságtervet pénzügyi krízisre dolgozták ki, de a jelenlegi helyzet következtében véleményem szerint másfajta krízistervekre is szükség van. Sikeres stratégiákat fontos lenne egymással megosztani. Ami a technológia tendenciákat illeti: a digitalizáció meg fog erösödni, akár a fizetőeszköz is megváltozhat. Sok helyen már most korlátozott a készpénzhasználat, erre is fel kell készülni. Mentalitásbeli különbségeket tekintve kevesebb tapasztalattal és szakmai tudással rendelkezünk, mint az idősebb generációk, de rugalmasabban alkalmazkodunk. Bízom abban, hogy valamilyen megoldás mindig van. Nem félek a változástól, de készülnünk kell rá.

Lits Levente: A gazdaság szerves része a társadalomnak és a társadalom tükröződik benne. A gazdaságban jelenlévő változások a társadalomban jelenlévő politikai, technológiai és értékrendi folyamatokon keresztül érthetők meg. A közgazdász társadalom tágan értelmezve mindig is a mainstream irányzatokat képviselte a tudományon belül, de mindig volt egy másfajta nézőpont is, ahol máshogy gondolkoztak a társadalmi problémákról. Amikor a gazdaság válságokra való felkészítéséről beszélünk, akkor valójában a társadalom válságállóképességéről, illetve az erre való felkészítésről beszélünk. Ennek értelmében a társadalom képes legyen a környezet és a saját viszonyaira reagálni, valamint bármilyen válságot kezelni.

Halász Mihály: Óriási szemléletváltásnak kell abban bekövetkeznie, hogy hogyan gondolkodunk a gazdaságról. Nem egy vákuumban létezik, ahogy azt Levente is kifejtette. A közgazdaságtan az erkölcstudományokhoz van legközelebb. Ilyen szempontból erkölcsi válságot élünk meg. Kérdés, hogy az emberiség túl tud-e ezen jutni és tud-e alternatívát kínálni. Nyilván a közgazdász társadalomnak is óriási ebben a felelőssége, hiszen nem tekinthetjük teljesnek a munkánkat, ha a gazdálkodó nem tud erkölcsösen viselkedni, mert a mi felelösségünk, hogy ő erkölcsösen viselkedjen.

\section{A fenti tendenciák hogyan fogják befolyásolni az Önök karrierjét? Hogy érzékelik, pályatársaik milyen karrieruta(ka)t képzelnek el magunknak? Önök szerint ezek mennyire reális elképzelések?}

Bencsik Ildikó: 5 éve dolgozom egy tanácsadó cégnél és a válság nem volt rossz hatással a cég müködésére, sőt, árbevétel növekedést tudott elérni. A karrieremet nem befolyásolta a válság. A cég létszáma körülbelül 60 fó, így az elszemélytelenedést sem éltem át a home office ellenére, nem úgy, mint mondjuk egy nagy multinacionális cégnél egy ott dolgozó átélhette. Ami a trendeket illeti, sok fiatal szeretne saját vállalkozásban dolgozni, az állami szféra pedig nem túl preferált. Sok mentorprogram és cég áll a fiatalok rendelkezésére, ami segíti őket saját vállalkozás indításában. Az ötletük validálását sok fiatal vállalkozó elfelejti, de egy tapasztalt személy sokat segíthet ebben.

Kunkli Gréta: Egy startup elindításában már én is gondolkoztam, de még nem most. Nagyon szeretnék sok mindent kipróbálni és megtanulni. Amint elég tapasztalatom és hozzáértésem lesz, akkor talán belevágnék egy ilyenbe. Ami a karrieremet illeti: jelenleg értékesítési asszisztensként dolgozom, de érdekel a rendezvényszervezés is. A munkám során szerzett tapasztalatok alapján vezetőképzéssel szeretnék foglalkozni majd a jövőben. Nem hiszem, hogy általánosságban olyan nagyon befolyásolná a közgazdászok életét a járvány. Mindig lesz szükség rájuk, talán most még inkább fontos a szerepük, mint valaha, mert átlátják, hogy mi fog történni és tudnak a kihívásokra reagálni. Pályatársaim közül sokan túlpozícionálják magukat és túl gyorsan szeretnének vezetők lenni.

Lits Levente: A 21. században kevesen szeretnének valódi felelősséget vállalni. Ez szerintem a posztmodern tér sajátja, hogy sokan a mának és a gyors pénzszerzési lehetőségnek élnek. Például Elon Musk esetében sokan nem a tanultságára figyelnek, hanem, hogy hogyan képes egy-egy mondatával a 
kriptovaluták árfolyamát befolyásolni. Pályatársaim közül sokan szeretnének külföldre menni tanulni és az a tapasztalatom, hogy aki kinn él már egy hosszabb ideig, nem nagyon tervez hazajönni.

Halász Mihály: Alapszakos csoporttársaim körében sokan multinacionális vállalatoknál kezdtek el dolgozni, alkalmazott közgazdaságtani diplomával. Közgazdasági elemző mesterszakon sokan dolgoznak az MNB-nél, de a multinacionális cégek ugyanúgy népszerüek. Kérdés, hogy mennyire szeretnének a hallgatók a döntéshozatalba bekapcsolódni. Volt például, hogy a Monetáris Tanács ülését szimuláltunk szeminárium keretében és azt sokan szerették, de a valódi döntés következményeitől az emberek általában félnek. Egyszerübb a háttérben dolgozni, mint a döntéshozatalba bekapcsolódni.

Kortársaikkal, más egyetemek vagy más szakok hallgatóival kommunikálva mennyire elismert a közgazdász szakma és a közgazdász diploma? Milyen a külső megítélése a szakmánknak? Tudunk-e, és ha igen, akkor hogyan esetleg ezen javítani? Hogyan tud hitelesebbé válni tudományunk?

Bencsik Ildikó: Egyetértek azzal, hogy a közgazdászok megítélése lehetne jobb, föleg a BME-n mérnökök közt közgazdászként végezve. A munka világában ezt nem tapasztaltam. Közgazdász végzettséggel sok helyen el lehet helyezkedni, és a társadalom szemében ez úgy csapódik le, hogy ha közgazdász vagy, bármire jó leszel. Nem tapasztaltam túl negatív dolgokat, inkább optimistán látom ezt a helyzetet.

Kunkli Gréta: A turizmus szakot sokan megfoghatóbbnak ítélik, emiatt nincs negatív megítélése az egyetemen. Munkakeresésnél határozattan örültek a közgazdász végzettségemnek, és emiatt sok plusz feladatot is kaptam a jelenlégi munkahelyemen. Nem tapasztaltam negatív visszajelzést a közgazdászokkal szemben.

Lits Levente: A Corvinuson alkalmazott közgazdaságtan szakos hallgatóként mindig próbálom a környezetemben felmérni a szakmám megítélését. Az a tapasztalatom, hogy a közgazdászképzést más egyetemi hallgatók nem tartják kellően színvonalasnak.

Halász Mihály: A közgazdász, mint szakma merre tart - az egy nagyon érdekes kérdés. Emberi életekről és sorsokról döntünk, amit sokan nem éreznek át. Ami a hivatásunkat illeti, nem szeretem a karrier szót, nemcsak amiatt, mert van egy kicsit neoliberális hagyománya, hanem inkább a weberi hivatástudatot tartom sokkal előrelátóbbnak és a közgazdászok számára mintaadónak.

Eddigi egyetemi tapaszalataik alapján hogyan alakítanák át a képzést? Milyen ismeretkörökre hangsúlyoznának inkább, melyekre kevésbé? Hogyan változtatnának a képzési formákon (szeminárium, elöadás vagy valami más)? Mit gondolnak a szakstruktúráról, amiben képezték Önöket? Változtatnánake a képzés hosszán?

Bencsik Ildikó: A mesterszakot a Müegyetemen közgazdasági elemző szakon végeztem. Azt minden szempontból tökéletesnek tartottam. 9-en voltunk, szinte minden óra beszélgetés volt az oktatókkal. Kiscsoportokban dolgoztunk, előadásokat tartottunk egymásnak. A mesterszakon szerintem maximum a 10-20 fö az ideális.

Kunkli Gréta: A tárgyak sorrendjét tekintve, az utolsó évekbe tennék menedzsment típusú tárgyakat, hogy így az addig megszerzett tudást egybe tudjam építeni. Tréningeket is tennék a képzésekbe, például karriermenedzsment, önfejlesztés, vezetőképzés. Üzleti szituációkat is jobban bevonnék a képzésbe. Kisebb létszámú oktatást szerveznék. 
Lits Levente: A tudomány demokratizálása az oktatáson keresztül valósítható meg. Az értékrend oktatását jobban előtérbe helyezném. Az egyetem során az ember, mint felnőtt lép be az iskolapadba, így saját érdeke a tudás megszerzése, hogy a társadalom hasznos tagjává váljon. Egy olyan oktatási modell lenne szerintem hatékony, ami a lehetőségekre és a képességekre épít. Sokkal nagyobb hangsúlyt kellene fektetni a száraz tananyag helyett a képességfejlesztésre.

Halász Mihály: Első lépésként új tankönyvek kellenek az alapozó tárgyakból. Mérlegelni kell, hogy hogyan oktassuk az egyes tárgyakat. Például menedzsment készségek átadását nem biztos, hogy egy levegőtlen tanteremben a táblánál kellene megszervezni. Tudományos mühelyek reneszánszukat élik, és ilyen kisebb csoportokban hatékonyabb lehet a tudásátadás és az értékrend közvetítése.

Az összefoglalót készítette Póta Krisztián ${ }^{1}$.

\footnotetext{
${ }^{1}$ egyetemi hallgató, Budapesti Corvinus Egyetem 